Book Review

\title{
TOWARD A PROGRESSIVE PUBLIC PROSECUTOR'S OFFICE: A STUDY ON INVESTIGATION, PROSECUTION AND ADJUDICATION OF CRIMINAL ACTS OF CORRUPTION
}

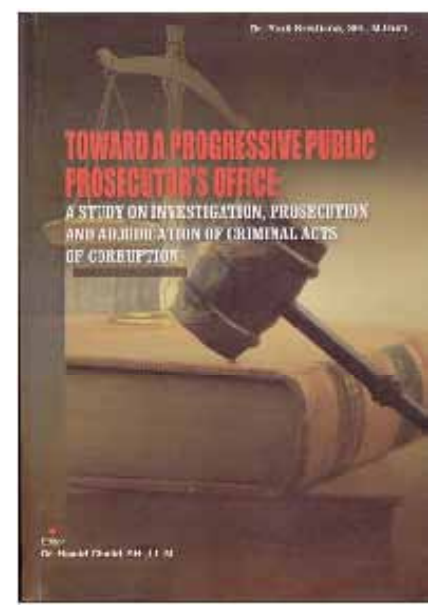

Toward a Progressive Public Prosecutor's Office: a Study on Investigation, Prosecution and Adjudication of Criminal Acts of Corruption (The Book) is one of the reliable resources in capturing the real picture of Indonesian Law Enforcement Institution-namely Attorney General Offices (AGO)- for its centralistic bureaucracy nature. Written by Dr. Yudi Kristiana, S.H., M.Hum. (Yudi), the idea of The Book came in reaction to 'the-never-ending' corruption phenomenon, ${ }^{1}$ its massive impacts and the underlying problems to eradicate corruption. ${ }^{2}$ Choosing one of the important stake holder to fight corruption, ${ }^{3}$ The Book is providing several reasons why the AGO seems not fully-functioned and successful in serving the justice for the state. The (allegedly) fault mainly lies upon AGO's conventional case-handling methods, which in general is bureaucratic and centralistic and adopts hierarchical accountability and the command system. ${ }^{4}$

The book had its genesis by constructing the importance of progressive law in Indonesian legal system to fight corruption. The philosophy of progressive law, its theory and relations to other law theories-like natural law, responsive law, legal realism- viewed as an accurate picture for Indonesian society. Yudi argued that people are likely to obey legal products accommodating the will of the community based on the values applicable in the community. Furthermore he stated that:

The enforcement of progressive law emerged among the confusion and depression of the nation of Indonesia culminating in the reformation period, including the crisis in law enforcement. Therefore, comprehensive thoughts were required to find the way out of depression. The implementation of law with conventional methods and business as usual manner did not help much the efforts to come out from legal crisis, in fact, law enforcement seemed to be walking in the same place. Therefore, like it

\footnotetext{
${ }^{1}$ Teten Masduki states his pessimistic view as follows: "From where and how can we begin the eradication of corruption if the abuse of authority has systematically penetrated all sectors at various levels in nonconductive political environment and bureaucracy? Meanwhile, the new government which is expected by the community to break the chain of corruption inherited by the old regime must also face difficulties in the economic, political and security sectors which are equally important to be solved at the same time. So far, many parties in Indonesia, including the government, are convinced that it is not easy to solve those problems. It must be considered as common problems which has been entrenched and must be faced with endless patience, while expecting for gradual improvement in a long term".

${ }^{2}$ Page $1-5$.

${ }^{3}$ Page 6.

${ }^{4}$ Page $7-8$.
} 
or not, extraordinary efforts are required to immediately release Indonesia from law enforcement crisis. That is why the idea of progressive law emerged. ${ }^{5}$

There are six chapters compiled in the book to answer the main question of how the AGO's bureaucracy system can operate effectively to investigate, prosecute and adjudicate criminal acts of corruption. The first and second chapters are explaining the main background and the basic theory concept (as stated above) to answer the main question.

Criminal justice system; integrated criminal justice system; criminal act of corruption and competency of AGO in criminal act of corruption are also construed aside from progressive law concept. On the third chapter, the reality of AGO's conventional bureaucracy approach in handling criminal act of corruption unfolds from investigation until prosecution phase. The main issue in this approach is mainly about control from the higher officer in AGO.

Chapter four put clearer picture of 'control' as the conventional bureaucratic nature in AGO in a frame of its discrepancy and other factors causing deviations in handling criminal act of corruption. By the end of this chapter, three irregular sample cases are given to emphasize the defect of AGO's bureaucratic system. ${ }^{6}$

In chapter five, the concept of progressive law offered as an approach to reconstruct AGO's office through bureaucratic structure, bureaucracy culture and policies (law and regulation). ${ }^{7}$ And finally, the last chapter concluded that AGO's bureaucratic and centralistic characteristics with hierarchical responsibility and command system is ineffective to contribute optimally during the investigation, prosecution and adjudication of corruption cases. ${ }^{8}$

One of the strongest point from The Book is the revelation of AGO's bureaucratic system, making us realize that there is a serious problem in AGO. Yudi conceals that discrepancy in the AGO's bureaucracy is institutionalized in the form of leadership discretion shrouded by five forms of performances. ${ }^{9}$ Its revelation from normative and empirical perspective put The Book's substance as controversial and interesting topic to discuss among Scholars, taking into account that not so many books could offer strong data and information per se.

Framing corruption cases as the main theme of The Book, Yudi segmented himself to do this research. AGO main function is to handle criminal cases, not corruption criminal cases. How is the handling of criminal cases then? Does it have the same bureaucratic system? Yudi did not come across this topic in The Book. Therefore, in this sense, The Book is slightly lack of something.

Nonetheless, Yudi still offers few comparison of AGO and other institution, at the same time bringing the topic into broader level and narrow conclusion. In conclusion, Toward a Progressive Public Prosecutor's Office: a Study on Investigation, Prosecution and Adjudication of Criminal Acts of Corruption deserves thoughtful reading by a wide audience in the legal academy and profession, as well as it can be a reliable source to discuss in class.

\footnotetext{
${ }^{5}$ Page 39.

${ }^{6}$ These irregular handling cases are Corruption of the Central Java Province's Local Revenues and Expenditures Budget (APBD) in the 2003 Budget Year (BY); Corruption of the Temanggung District APBD in the 2003 Budget Year; and Corruption at Pertamina's UPMS IV of Semarang.

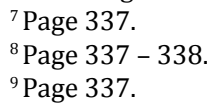

